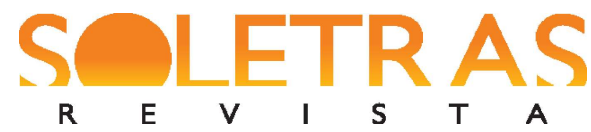

DOSSIÊ-N. 35 - 2018.1 - ISABEL CRISTINA RANGEL MORAES BEZERRA

\title{
"Eles eram capazes de refletir sobre questões importantes e delicadas": construindo saberes através de um projeto de iniciação à docência de LIC
}

\author{
Isabel Cristina Rangel Moraes Bezerra ${ }^{1}$
}

\begin{abstract}
Resumo: A formação de docentes na graduação de Letras (Português/Inglês) nas universidades brasileiras não costuma oferecer disciplinas voltadas para o ensino de língua estrangeiras para crianças (LEC) ou, como no caso em análise, de língua inglesa para crianças (LIC), apesar da demanda em escolas particulares e em algumas redes de ensino público. Nesse cenário, insere-se a proposta do projeto de ID que coordeno, o qual visa oferecer um espaço discursivo para a construção de saberes e para o pensar crítico sobre esse ensino-aprendizagem. Assim, com base em pesquisa na área (PINTER, [2006]2015; SEGANFREDO; BENEDETTI, 2009; CRISTÓVÃO; GAMERO, 2009), apresento pressupostos teóricos para fundamentar uma proposta de LIC, bem como para a formação do professor para esse segmento. Apoiada na abordagem híbrida para o ensino-aprendizagem, formação docente e reflexão da Prática Exploratória e em seus princípios (ALLWRIGHT, 1996; MILLER, 2013),ao invés de resultados, trago alguns entendimentos sobre a formação inicial de professoras de inglês a partir do projeto de iniciação à docência em tela na voz de uma bolsista. Tais entendimentos locais podem, por sua vez, contribuir para aprofundar as discussões em curso na área de ensino de inglês para crianças e formação inicial de professores de inglês para esse público.
\end{abstract}

Palavras-chave: Formação docente inicial. Prática Exploratória. Ensino de inglês para crianças. Letramento crítico.

\section{Ensinar inglês para crianças cada vez mais cedo...}

O ensino de inglês para crianças é um tema que precisa ser constantemente revisitado devido à grande pressão mundial para que a língua inglesa faça parte do currículo escolar cada vez mais cedo (CAMERON, 2001; ROCHA, 2007; SANTOS; BENEDETTI, 2009). Há países na América Latina que já fizeram a inclusão compulsória do ensino desse idioma nos currículos para crianças desde o início de sua escolarização, afetando políticas públicas de educação e de formação docente (BANFI, 2015). É o caso da Argentina (PORTO, 2016) e do Chile (ARAOS, 2015), por exemplo. No Brasil, embora ainda não tenha havido um movimento no sentido da inclusão oficial da língua inglesa no currículo da Educação Infantil, ou mesmo do Ensino Fundamental I, há muitas escolas da rede particular e do setor de escolas de idiomas que ofertam aulas de inglês para os pequenos aprendizes (MILLER, et al, no prelo). Essa tendência encontra-se em expansão, alcançando, inclusive, o ensino público em alguns estados brasileiros como o Rio de Janeiro, através de iniciativas das cidades do Rio de Janeiro e de Niterói.

1 Doutora em Letras pela PUC-Rio. Atualmente, é professora adjunta da Universidade do Estado do Rio de Janeiro (UERJ), São Gonçalo, RJ, Brasil. É líder do Grupo de Pesquisa Núcleo de Estudo e Pesquisa de Prática Exploratória (NEPPE), membro do Grupo de Pesquisa Linguagem e Sociedade, membro do GT Formação de Educadores na Linguística Aplicada.icmoraes@uol.com.br. 


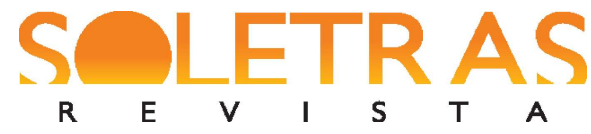

DOSSIÊ-N. 35 - 2018.1 - ISABEL CRISTINA RANGEL MORAES BEZERRA

Nesse cenário global e local, há pais que acreditam ser relevante para os filhos aprenderem inglês considerando uma possível competitividade no mercado de trabalho no futuro e em que se veem mobilizados por discursos que alegam haver vantagens sociais para crianças que se submetem à educação bilíngue - embora como Miller et al. (no prelo) aconselham, isso deva ser cuidadosamente pensado. Por isso, os responsáveis buscam escolas e cursos de idiomas em que seus filhos possam, desde cedo, aprender inglês. Essa oferta, porém, necessita ser construída para levar em consideração peculiaridades dos pequenos aprendizes (ROCHA, 2007; MILLER, et al, no prelo). Deve ser feita a partir de uma interação significativa, de respeito e de articulação do conteúdo a aspectos sociais, culturais e afetivos trazidos pelas crianças para as práticas em sala de aula. Além disso, como apontou Cameron (2003), não há bases de pesquisa teórica e empírica firmes sobre ensino de inglês para crianças. Seria preciso, sobretudo, investir nesse campo para que reflexões e entendimentos emergentes e locais possam servir de base para propostas de Língua Inglesa para Crianças (LIC) que atendam ao grupo a que se destinam.

Como não há uma obrigatoriedade na oferta de LIC/LEC nas políticas de ensino do Brasil, não há, igualmente, um documento que sirva de parâmetro para o ensino desse idioma ou de qualquer língua estrangeira para crianças. Isso significa que tanto as escolas da rede particular quanto as da rede pública em diferentes municípios que já oferecem LIC têm propostas com encaminhamentos diversos, dependendo da equipe que se haja reunido para propor as diretrizes. As escolas da rede pública, via de regra da rede municipal, seguem a orientação das secretarias de educação, podendo ter ou não a assessoria de especialistas e pesquisadores vinculados a universidades para a formulação do currículo, construção da proposta metodológica, recorte de conteúdos etc. Cito como exemplo uma proposta para as escolas públicas gerada em Londrina através de um trabalho colaborativo de diferentes segmentos envolvidos com a educação (linguística). Trata-se do Guia Curricular para a Lingua Inglesa (LONDRINA, 2013). Na apresentação desse documento, explica-se: "Nele apresentamos orientações pedagógicas a professores que buscam diretrizes para o Inglês da educação infantil ao $5^{\circ}$ ano da educação básica" (LONDRINA, 2013, p. 5). Ele foi produzido colaborativamente por professores da rede municipal, representantes da secretaria municipal de educação, professores e alunos da Universidade Estadual de Londrina. Esse, a meu ver, deve ser o encaminhamento mais ético para a proposta de LIC, uma vez que os pequenos aprendizes demandam uma abordagem de ensino particular. É o que passo a tratar a seguir. 


\title{
Ensino de inglês para crianças - o que considerar?
}

Toda e qualquer ação educativa deve levar em conta o 'porquê' de se estar levando-a adiante, o 'para quê' ela é proposta,'para quem' ela se dirige e 'quem' se beneficia com ela. Por isso, trago a voz de Rajagopalan para ajudar na reflexão sobre o ensino de LIC, pensando o macro contexto social, geopolítico e econômico. Em entrevista concedida à Revista de Letras Norteamentos (2011, p.7), esse linguista aplicado faz a seguinte reflexão sobre o ensino de LIC:

\begin{abstract}
Essa pergunta não pode ser respondida com sim ou não, não é uma pergunta tão fácil. Eu digo, a questão mais importante não é que idade deve começar. [...] A gente tem que pensar o ensino/aprendizagem de línguas no contexto maior, ou seja, é uma sociedade. Ensino de língua não é brincadeira. Nesse contexto que nós estamos vivendo, o contexto de globalização, países estão investindo pesadamente nesta questão. Então, a gente tem que perguntar para que a sociedade brasileira precisa que seus cidadãos tenham acesso às línguas? Isso é uma questão de geopolítica. Se o Brasil precisa de línguas, então a gente tem que pensar nesta questão. Uma vez estabelecida a prioridade, a gente tem que perguntar: qual a maneira melhor,quais os métodos a serem usados?
\end{abstract}

Ressalto de sua colocação o fato de que ensinar língua 'não é brincadeira' e entendo esse fragmento como uma observação para que os envolvidos na tarefa de ensinar inglês para crianças - professores, supervisores, produtores de material e livro didático - não encarem essa atividade como algo acrítico, sem consequências para a formação integral dos pequenos aprendizes, como uma atividade que pode ser feita abstraindo-se o mundo social e a relação com o outro em um mundo plural, multicultural, descuidando da construção de atitudes positivas da criança em relação às naturais diferenças que fazem dos seres humanos o que são. Obviamente é preciso pensar em quem são esses pequenos aprendizes, quais são seus interesses, como é possível engajá-los de forma significativa no processo de ensinoaprendizagem. Rocha (2007) colabora chamando atenção para alguns pontos relevantes que devem ser considerados em propostas de ensino de línguas estrangeiras para crianças (LEC):

[...] podemos citar a importância de o processo estar voltado para os interesses do aluno, o fato de não tomarmos o desenvolvimento das habilidades linguísticas como foco único do processo e a necessidade de entendermos esse ensino como capaz de proporcionar melhor embasamento para uma aprendizagem efetiva da LE em séries posteriores (ROCHA, 2007, p.277). 


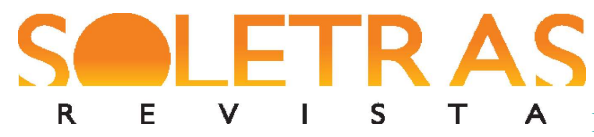

DOSSIÊ-N. 35 - 2018.1 - ISABEL CRISTINA RANGEL MORAES BEZERRA

Outra questão apontada por Rajagopalan, diz respeito ao encaminhamento metodológico. Para configurar uma abordagem de ensino-aprendizagem para LIC, ou para qualquer faixa etária, baseio-me em postulados da teoria sócio-histórica cultural, conforme proposta por Vygotsky (1998, [1987] 2008). Esse autor discutiu a formação social da mente, ou seja, os processos de cognição que, segundo ele, são fruto de uma dinâmica cognitiva atrelada ao social, à história e à cultura, sendo a linguagem elemento fundamental para a construção conjunta de conhecimentos. Vygotsky (1998, p. 111) entende que o aprendizado da criança deve ser combinado com seu nível de desenvolvimento. Portanto, é preciso identificar dois níveis. O primeiro é o nível de desenvolvimento real o qual diz respeito às funções mentais que já se estabeleceram, sendo resultado de certos ciclos de desenvolvimento. É o que a criança aprendeu e é capaz de dar conta sem ajuda ou mediação por parte de um par mais competente que pode ser um adulto ou mesmo outra criança. Já o nível de desenvolvimento potencial, que se configura nas tarefas/atividades/problemas que ela ainda não consegue fazer sozinha, os conhecimentos ainda não estão construídos posto que ela precisa da ajuda de outrem para dar conta da tarefa, para entender determinados conceitos (cotidianos ou escolarizados/científicos), para resolver problemas. $\mathrm{Na}$ interface desses dois níveis, em situação de aprendizagem, emerge a zona de desenvolvimento proximal [ZDP], i.e., a distância entre o que o aprendiz consegue fazer com autonomia e o que só consegue fazer ou solucionar sob a orientação de pessoas que já tenham internalizado os conhecimentos necessários para tal.

Vygotsky ([1987] 1998, p. 113) entende que a ZDP "caracteriza o desenvolvimento prospectivamente" e que “o 'bom aprendizado' é somente aquele que se adianta ao conhecimento". Dessa forma, e através da repetição de eventos interacionais e do emergir de ZDPs ao longo do tempo, o conhecimento necessário para dar conta de uma determinada atividade que estava no nível de desenvolvimento potencial, pelo processo interacional, passa a fazer parte do nível de desenvolvimento real do aprendiz. Em outras palavras, o processo interpessoal de construção de conhecimentos mediado pela linguagem, e, muitas vezes, pela ação, também ocorre no âmbito intrapessoal, sem, contudo, ser um reflexo ou cópia daquele ocorrido no âmbito interpessoal, gerando as funções superiores de pensamento. Onrubia, inclusive, ressalta esse fator da interação e do auxílio ajustado à situação de aprendizagem como fundamentais para a ZDP e a construção da autonomia do aprendiz: 
Portanto podemos afirmar que oferecer uma ajuda ajustada à aprendizagem escolar supõe criar ZDP e oferecer nelas ajuda e apoio para que, por meio dessa participação e graças a esses apoios, os alunos possam ir modificando, na própria atividade conjunta, seus esquemas de conhecimento e seus significados e sentidos, e possam ir adquirindo mais possibilidades de atuação autônoma (ONRUBIA, 1999, p.129).

A 'ajuda ajustada' na perspectiva de Onrubia é importante pelo potencial de conectar o conhecido ao que é preciso conhecer, pois "se de alguma forma não estiver conectada aos esquemas de conhecimento do aluno, se não for capaz de mobilizá-los e ativá-los e, ao mesmo tempo, forçar sua reestruturação, não estará cumprindo efetivamente sua missão" (ibid. 1999, p.125). A tarefa ou problema propostos ao aprendiz deve se constituir pelo que o autor chama de um 'desafio abordável'(ONRUBIA, 1999, p.126), ou seja, aquele que o aprendiz pode enfrentar pela combinação de suas próprias possibilidades e ajuda/instrumentos oferecidos pelo professor. Considerando os pequenos aprendizes de LIC, isso pode acontecer, por exemplo, usando a língua materna como ponto de partida - a língua conhecida - para se chegar à língua estrangeira - a língua por conhecer e usar para seus próprios intentos dentro de seu campo de ação na escola ou fora dela.

Para as crianças, em particular, segundo Vygotsky, a brincadeira é fundamental para o aprendizado e, consequentemente, para a construção dessas funções. Conforme o autor ([1987]1998, p. 126), “É no brinquedo que a criança aprende a agir numa esfera cognitiva, ao invés de numa esfera visual externa, dependendo das motivações e tendências internas". Essa ação envolve imaginação e o uso de abstração, uma vez que "é alcançada uma condição em que a criança começa a agir independentemente daquilo que vê" (VYGOTSKY, [1987]1998, p.127). Se considerarmos a construção de conceitos escolares, inclusive a aprendizagem de línguas, o brincar ocupa um lugar de relevância, envolvendo aspectos cognitivos, afetivos e motivacionais, podendo ser ponte entre o concreto e a abstração.

A segunda questão a fundamentar uma proposta de ensino para LIC ou qualquer nível de educação linguística, diz respeito à forma como a língua é pensada, o que encaminhará como o componente linguístico será abordado. Refiro-me às possibilidades de se entender a natureza da linguagem em uma perspectiva estrutural, de comunicação ou sociointeracional (BRASIL, 1998; MORAES BEZERRA, 2000; MILLER, MORAES BEZERRA, 2007). Para minha prática docente e de orientação no projeto de ID, parto dos seguintes entendimentos: o uso da língua é uma forma de estar e agir no mundo social em que os usuários dessa língua

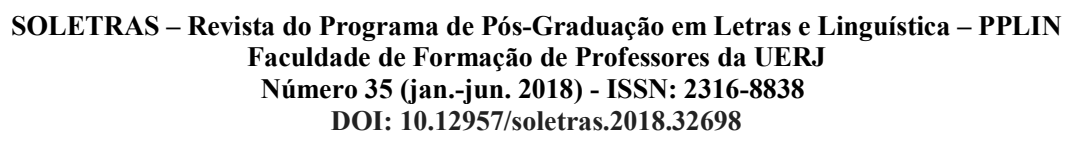




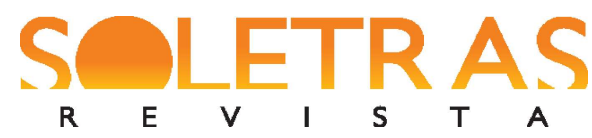

DOSSIÊ-N. 35 - 2018.1 - ISABEL CRISTINA RANGEL MORAES BEZERRA

utilizam-se de uma grande multiplicidade de gêneros discursivos; os significados não estão prontos nem antecedem a interação; o uso da língua é parte, permeia e configura práticas sociais e o conhecimento, engendrando relações de poder e reações ao poder, (re)construindo identidades múltiplas e fragmentadas (BAKTHIN, 1981; FAIRCLOUGH, 1989, 1992, 1995; MOITA LOPES, 1996, 2003; BRASIL, 1998a; BRASIL, 2006). Além disso, no ensino, é preciso construir uma perspectiva crítica em relação ao uso social da língua configurada a partir da proposta do letramento crítico (JANKS, 2016).

Acompanho Rocha (2007) e Cristóvão e Gamero (2009) que defendem um ensino de LIC fundamentado em gêneros discursivos. Entendo, como Cristóvão e Gamero (2009, p. 231), gêneros discursivos a partir de uma perspectiva bakhtiniana e seu uso no ensino de línguas conforme citação que se segue:

[..] os gêneros são artefatos simbólicos que possibilitam a realização de ações em situações de comunicação específicas com percepção do contexto (quem, para quem, quando, onde, sobre o quê, como e para quê/porquê) e de artefatos materiais (linguísticos, inclusive e principalmente). $\mathrm{O}$ ensino com base em gêneros teria como pressupostos que a aprendizagem desses artefatos tanto pode contribuir para seu agir no mundo como pode conferir ao aprendiz um senso de autoria, agência e autonomia possibilitando-lhe questionar aquele agir e/ou seu próprio artefato (CRISTÓVÃO, GAMERO, 2009, p. 231)

Bazerman $(2005$, p.19, 23) aponta que "as pessoas criam novas realidades de significação, relações e conhecimento, fazendo uso de textos" e que, na vida cotidiana, "ao introduzir esses diferentes textos, vocês não estarão apenas introduzindo diferentes tópicos, mas introduzindo diferentes atividades, padrões interativos, atitudes e relações”. Portanto, seja na aprendizagem de língua materna, quanto na de língua estrangeira, para alunos de qualquer idade, o trabalho pedagógico a partir de gêneros se faz fundamental para introduzi-los em práticas discursivas outras, além daquelas com as quais estão familiarizados. Particularmente no que tange a LIC, jogos, histórias e canções infantis devem ser a base para o trabalho com a língua e podem projetar ou se estender para outros gêneros mais escolarizados que propiciem o avanço e o uso da língua em situações significativas e contextualizadas. Por exemplo, na construção de um pôster como parte de atividades de um projeto sobre tipos de moradias em um processo reflexivo sobre quem tem acesso a morar com dignidade. $\mathrm{O}$ trabalho poderia partir de perguntas como: Onde elas podem ser encontradas? Que pessoas as habitam? Como são construídas? Porque foram construídas no formato encontrado e com um determinado tipo 


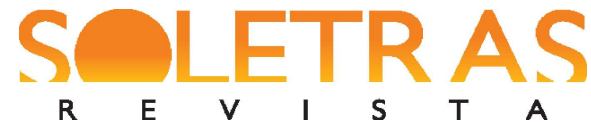

DOSSIÊ-N. 35 - 2018.1 - ISABEL CRISTINA RANGEL MORAES BEZERRA

de material? Por que nem todas as pessoas moram em lugares com acesso a escolas e postos de saúde?

As perspectivas sobre gênero e ensino se alinham à visão da natureza sociointeracional da linguagem, conforme mencionada acima. Ademais, apontam para outra questão que, a meu ver, deve também estar vinculada ao ensino de línguas através de gêneros que transcende a estrutura retórica e os atrela ao contexto sócio-histórico e cultural de produção e de circulação. Refiro-me ao letramento crítico, conforme Janks (2016) que, logo na introdução do capítulo, aponta como a relação leitor-autor mediada e marcada pelos textos que circulam nas diferentes práticas de letramento nas quais nos envolvemos diariamente deve ser considerada. Nesse sentido, afirma a autora:

[...] precisamos ter em mente que textos têm efeitos sociais, construídos para dar uma versão "da verdade". Assim a língua pode ser usada para diferentes propósitos. Saber que textos não são neutros nos conclama a desenvolver caminhos para ver de onde eles vêm e reconhecer como são designados por nós, os leitores. Isso não quer dizer que todo produtor de texto tem como objetivo manipular seus leitores. Quando nos comunicamos, nós todos queremos que as pessoas passem a concordar conosco. Nosso trabalho como ouvintes ou leitores é entender a posição de quem fala ou escreve e decidir se eles se mantêm ou não na mesma postura (JANKS, 2016, p. 21).

Janks faz um convite à prática do estranhar o que está naturalizado; a olhar os textos e questionar a postura do autor; a questionar situações que antes não chamavam a atenção, passando a notar o que era ignorado; a pensar sobre quais interesses estão sendo atendidos através da maneira como uma dada temática é abordada e que posicionamento é assumido por quem escreve em relação a ela; à seleção lexical e às estruturas sintáticas usadas para construir o texto, assim como às imagens, aos gráficos e outros elementos semióticos usados para dar suporte ao posicionamento assumido. Com isso, abre-se espaço para entender que "poder, acesso, identidade e diferenças, juntos, são questões interconectadas pela linguagem" (JANKS, 2016, p. 22). Certamente os pontos discutidos acima, especialmente em relação aos gêneros e ao letramento crítico, no que tange à LIC, precisariam ser tratados de acordo com o momento vivido pelos pequenos aprendizes o que nos leva a uma questão de extrema preocupação: a formação do professor de LIC. Nessa área urge pensar como tem sido construído o processo formativo inicial e continuado desse profissional; qual a visão do pequeno aprendiz que ele tem e como ela afeta a sua prática; qual a base teórica sobre 


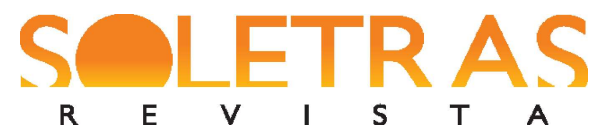

DOSSIÊ-N. 35 - 2018.1 - ISABEL CRISTINA RANGEL MORAES BEZERRA

aprendizagem e linguagem subjaz em essa formação. É sobre isso que reflito na próxima seção.

\section{Formação docente para o trabalho com Língua Inglesa para Crianças}

$\mathrm{Na}$ contramão da tendência de expansão do ensino de LIC no Brasil, a formação do professor para atuar com aprendizes dessa faixa etária não tem recebido a atenção que deveria dos cursos de graduação. A maioria dos cursos de Letras não está preparada para dar conta da formação docente para atuação com LEC/LIC de um modo geral (SEGANFREDO; BENEDETTI, 2009; CRISTÓVÃO; GAMERO, 2009). Por outro lado, os cursos de Pedagogia preparam o profissional para trabalhar com a criança, mas não há formação específica para o ensino de língua inglesa. Santos (2006) e Rocha (2006) apontaram ainda não haver parâmetros ou indicações precisas sobre como deva ser conduzida a formação do professor de LIC no Brasil exatamente por não haver uma formação profissional inicial, eu diria mesmo continuada, específica. O que se identifica são ações isoladas como a oferta de uma disciplina eletiva na Universidade Estadual de Londrina e quatro cursos de pósgraduação lato sensu de acordo com a pesquisa de Cristóvão e Gamero (2009). Talvez hoje, quase dez anos depois, esse panorama tenha sofrido modificações; contudo, se aconteceram, ainda não são perceptíveis. Cabe registrar, como movimento mais recente que tenho notícia, a iniciativa da professora Janaína Cardoso da UERJ e de duas de suas orientandas de mestrado que estão oferecendo a primeira edição de um curso voltado para professores de LIC.

De acordo com Pinter ([2006]2015, p.41), para que se introduza satisfatoriamente o inglês nas escolas primárias em qualquer país, é preciso que o governo invista na formação docente inicial e continuada dada a carência de professores qualificados. Mas no que consistiria estar capacitado para atuar nesse nível de ensino? É ainda Pinter ([2006]2015) que ajuda a encaminhar a resposta: é preciso conhecimento (proficiência) da língua inglesa e do currículo de forma a integrar o ensino do idioma nas atividades diárias das aulas. No Brasil, em relação à educação infantil, o Referencial Curricular Nacional para a Educação Infantil [RCNEI] (BRASIL, 1998b) indica o perfil de professor para trabalhar nesse nível de ensino que envolve: competência polivalente com vistas à formação profissional ampla, busca constante por conhecimento, reflexão sobre a prática, dentre outras. Ainda que tais características não tenham sido propostas para o professor de LEC/LIC, podem servir como 


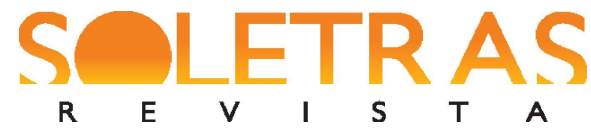

DOSSIÊ-N. 35 - 2018.1 - ISABEL CRISTINA RANGEL MORAES BEZERRA

referência. Rocha (2007) defende que esse professor precisa desenvolver habilidades específicas e, apoiada em Cameron (2003), afirma que

além de possuir conhecimento da língua que ensina, ou seja, ser um falante competente linguística e sócio-culturalmente da língua alvo, o professor precisa estar capacitado a iniciar o processo de letramento da criança na LE, ter conhecimentos a respeito de como a criança se desenvolve, pensa e aprende línguas (ROCHA, 2007, p.284).

Concordo com os apontamentos das autoras citadas e as indicações do RCNEI, porém trago mais um aspecto que pode fazer parte da formação do professor de LEC/LIC e que se orienta por um movimento constante de focar a qualidade da vida (GIEVE; MILLER, 2006) que se vive no espaço-tempo da sala de aula, envolvendo todos que ali estão trabalhando nas tarefas de ensinar e aprender. Trata-se da Prática Exploratória que, em sua proposta investigativa, inclusiva e ética, agrega ensino-aprendizagem-reflexão. Segundo Miller (2013, p.111) "a prática exploratória promove a integração das pessoas (professores, futuros professores, alunos e formadores de professores ou outros profissionais) e de suas atividades à busca de entendimentos aprofundados de suas questões da vida em sala de aula, na escola". Essas questões ou puzzles (ALLWRIGHT, 1999; MILLER, 2010; MORAES BEZERRA, 2003), encaminham o fazer exploratório. Concretizam-se através de perguntas propostas pelos praticantes, como algumas produzidas por alguns de meus licenciandos: "Por que ficamos nervosos antes do estágio? ' Por que é tão difícil para mim planejar uma aula sobre gêneros?' 'Por que os alunos da escola do estágio estão sempre interrompendo a professora?' 'Por que a professora do estágio passa tradução?' 'Por que as aulas de fundamentos da faculdade estão me interessando tanto? 'Por que há professores de estágio que não nos escutam? 'A partir delas, encorajo-os a refletirem durante o processo e a construírem portfólios/pesquisa durante o estágio ou a disciplina para registrarem diferentes etapas de construção de entendimentos. Esse fazer dialoga com a pedagogia da pergunta na perspectiva freireana (FREIRE; FAUNDEZ, 2011, p.74) uma vez que "o educando, inserido num permanente processo de educação tem de ser um grande perguntador de si mesmo. [...] A questão não está simplesmente introduzir no currículo o momento das perguntas, de nove as dez, por exemplo. [...] A questão nossa não é burocratização das perguntas, mas reconhecer a existência como um ato de perguntar". 


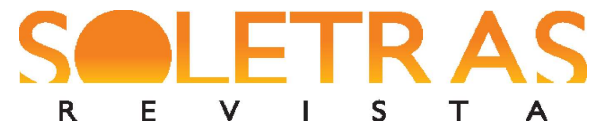

DOSSIÊ-N. 35 - 2018.1 - ISABEL CRISTINA RANGEL MORAES BEZERRA

Idealizada por Allwright, a Prática Exploratória defende uma postura antitecnicista, segundo a qual não é o domínio das técnicas por parte do professor que garantirá o sucesso escolar do aluno e, dessa forma, não se volta para a ação irrefletida de solucionar problemas identificados nas práticas sociais/escolares. Aliás, é preciso questionar sob qual ponto de vista se pensa em 'sucesso' no contexto escolar e até o uso dessa palavra. Considerando a complexidade da vida social em sala de aula, e da vida enfim, o sucesso poderia ser pensado como resultando na construção de relações interpessoais solidárias, em trocas que enriqueçam todos os participantes, pois "o que quer que façamos em termos de desenvolvimento do professor, precisamos ter em mente a delicadeza das relações entre as pessoas" (ALLWRIGHT, 1999, p. 10).

Ao tratar do burnout [ou esgotamento] gerado por demandas institucionais para eficácia do ensino e para o sucesso escolar, pelo relacionamento entre alunos e professores no cotidiano escolar, inclusive em sua formação inicial, e ainda relacionando-o à qualidade de vida, conforme a perspectiva da Prática Exploratória, Allwright (2008, p.136) assim coloca:

\footnotetext{
Considerar o burnout como uma questão de qualidade de vida (ao invés de qualidade de trabalho) nos ajuda a voltar a pensar no ensino de línguas como uma questão fundamentalmente humana, pessoal e interpessoal. Libertos de uma limitação tecnicista visando buscar salvação através do controle e mudanças técnicas, podemos, ao invés disso, focar na dimensão humana. Podemos igualmente fugir de uma abordagem para solução de problemas inerente à perspectiva tecnicista e pensar em termos de tentar entender a situação humana na sala de aula e na qualidade de vida nesse contexto.
}

Das duas citações acima, destaco 'a delicadeza das relações entre as pessoas' e 'o pensar o ensino de línguas como questão humana' por considerar essas questões de maior relevância quando se pensa em LEC/LIC pela faixa etária dos aprendizes, pelo processo de socialização escolar, pelos processos de letramento que viverá. A ação pedagógico-discursiva dos docentes em todos os níveis, e mais especialmente para os aprendizes em foco, acredito, têm implicações locais para a construção identitária dos aprendizes e para que eles sintam-se acolhidos, respeitados. Em outras palavras, nas práticas discursivas escolares em que linguagem e aprendizagem são indissociáveis, há consequências sociais, identitárias e afetivas, sobretudo para crianças em escolarização inicial.

Como professores atuam em contextos em que, via de regra, busca-se a solução de problemas, pode parecer difícil operacionalizar o'trabalhar para entender' ao mesmo tempo 


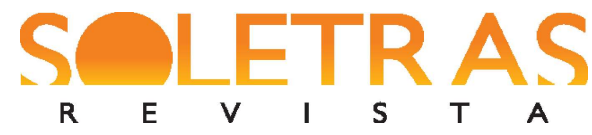

DOSSIÊ-N. 35 - 2018.1 - ISABEL CRISTINA RANGEL MORAES BEZERRA

em que se ensina e aprende, reenquadrando, ou ressignificando, 'problemas' e questionamentos trazidos pelos aprendizes como 'oportunidades de aprendizagem' (learning opportunities, ALLWRIGHT, 2005). O fazer da Prática Exploratória, para isso, inclui as Atividades Pedagógicas com Potencial Exploratório [APPE]. São atividades familiares aos docentes e que sofrem alguma adaptação para envolver os aprendizes no processo reflexivo em que se aprende e, ao mesmo tempo, trabalha-se para gerar entendimentos. Esse viés promove a sustentabilidade do trabalho reflexivo e constitui-se a base para o projeto de Iniciação à Docência que construo com as bolsistas. Dessa forma, elas são encorajadas a olhar e a ouvir com mais cuidado, 'problematizando' e 'refletindo sobre' a própria prática docente em construção. Esse movimento tem, inclusive, gerado monografias de conclusão da graduação (SILVA, 2015; BERNACHI, 2016; FERREIRA, em andamento; RODRIGUES, em andamento; SANTOS, em andamento). Esse exercício evidencia uma postura alinhada à formação reflexiva do professor pesquisador que teoriza o fazer em construção e que, em nosso projeto de ID, configura uma prática estimulada desde o início.

Ao problematizar a investigação no campo da formação de professores em Linguística Aplicada a partir do paradigma qualitativo, Miller $(2013$, p.112) afirma que as pesquisas têm se afastado “da concepção de resultados como 'produto', permitindo conceber resultado como 'processo" e destaca que esse aspecto processual leva a considerar os 'entendimentos' - e não os 'resultados'- como tendo "maior relevância intrínseca para as pessoas envolvidas do que para sua produtividade ou eficiência profissional" (ibid.). Alinhada a essas colocações, entendo que a formação inicial ou continuada do professor de LIC ou qualquer outro nível de ensino precisa ser relevante para os envolvidos, destacando seu aspecto processual, contextual, cultural, histórico e social. Precisa ser significativa, favorecer a construção de conhecimento teórico-prático que possa servir de base e ser transformado ao longo da vida profissional. Da mesma forma, precisa ser entendida como via de mão dupla entre licenciandos e professores formadores, entre licenciandos, professores regentes e alunos de escolas onde atuem em atividades de estágio ou de projetos de iniciação à docência através de uma escuta cuidadosa de si e do outro. Para isso, tanto licenciandos como alunos devem ser encorajados a construírem espaços de agência para a transformação ao trabalharem para entender questões relativas ao mundo social e ao mundo da sala de aula [mundos não excludentes, mas imbricados] que afetam a qualidade do aprender e do ensinar. Para 
Allwright, a questão do trabalhar para entender e não para controlar está no cerne da formação docente, construindo o espaço da reflexividade:

Porque esse trabalho para entender, na sala de aula de línguas, é algo que pode ser integrado na pedagogia e, portanto, faz mais sentido, acredito, tentar auxiliar professores de línguas desde o começo de suas carreiras, a entender esse fato e a aprenderem como fazer o melhor uso possível disso para usá-lo como apoio para seu próprio desenvolvimento profissional ao longo de suas carreiras. (ALLWRIGHT, 1996, p.9)

Portanto, com base na abordagem baseada em puzzles [puzzle-driven approach] (MILLER, 2009), a proposta da Prática Exploratória oportuniza a configuração de referencial teórico-metodológico para a prática reflexiva em formação, mobilizando professores em formação não apenas a considerarem o aspecto lúdico-afetivo da aprendizagem, mas, igualmente, as questões do mundo social de dentro e de fora da sala de aula que reverberam nas práticas discursivas a cada aula. É nessa perspectiva que propus um projeto de iniciação à docência voltado para LIC e que apresento a seguir.

\section{O projeto de iniciação à docência - arquitetura teórica e proposta formativa}

$\mathrm{Na}$ instituição de ensino superior onde o projeto de iniciação à docência "Ensino de Inglês Para Crianças: Formando Professores Reflexivos” é construído por mim e minhas alunas, a ideia de formação além das quatro paredes da sala de aula já é antigo e deu origem a diferentes possibilidades de aprendizagem e atuação de alunos da graduação de diversos cursos de licenciatura. Na verdade, esse processo formativo adicional na instituição disponibiliza bolsas de Iniciação à Docência (ID), Estágio Interno Complementar (EIC), Iniciação Científica (IC) e Monitoria desde a década de 90. O trabalho de professores orientadores com a iniciação à docência, portanto, é anterior ao programa de iniciação à docência proposto pelo governo federal e conhecido como PIBID. Cada projeto é encaminhado de acordo com uma proposta elaborada pela professora orientadora a partir de pressupostos teóricos que julgue mais relevantes para os objetivos definidos e para a abordagem que encaminhará a prática dos bolsistas. A participação nos projetos dessas 
categorias envolve um processo seletivo ${ }^{2}$. Conforme documento disponível online, essas possibilidades de atuação discente em ID compreendem:

[...] o conjunto de atividades ligadas a projetos que estimulem o desenvolvimento e a utilização de metodologias inovadoras que venham a contribuir na qualidade da educação básica e do ensino médio. É voltado, portanto, para alunos de graduação das áreas de Licenciatura. Os projetos serão desenvolvidos durante o período letivo, exceto aqueles que justificarem o início em outro período [...] [Devem estimular] o desenvolvimento e a utilização de metodologias inovadoras que interfiram na melhoria do ensino, sob orientação de um professor. Visa-se proporcionar ao aluno, especialmente o de licenciatura, a possibilidade de ampliar seu conhecimento e espírito crítico através do exercício concreto da docência, sob supervisão.

Fonte: http://www.cetreina.uerj.br/cetreina/modalidades de bolsa.html

Assim, os projetos de ID fazem parte do Programa de Bolsas-Auxílio para atividades discentes que visa a "incentivar a participação de alunos do curso de graduação em atividades acadêmicas, através de sua atuação em projetos e planos de trabalho específicos" (REITORIA, 1999). Segundo o AE-027³, publicado em 1999 pela reitoria, os objetivos específicos de tais projetos da instituição com relação aos alunos selecionados pelos professores para integrarem a equipe de trabalho do projeto são:

Art. $3^{\circ}$ - São objetivos específicos do Programa de Bolsas-auxílio para Atividades Discentes:

a) Complementar a formação acadêmica;

b) Aprofundar a participação na vida universitária;

c) Estimular o desenvolvimento de novas práticas e experiências pedagógicas, visando a melhoria do ensino;

d) Incentivar o desenvolvimento de programas e projetos considerados estratégicos para a Universidade;

e) Estimular, indiretamente, a melhoria do ensino de graduação, através do efeito multiplicador da ativação de um grupo de alunos junto ao corpo docente e discente;

f) Estimular a permanência do aluno na Universidade, reduzindo a evasão.

\footnotetext{
${ }^{2}$ Para os projetos de IC, ID e EIC, o professor orientador do projeto define o formato da seleção. Para Monitoria, contudo, há uma normatização da instituição que indica etapas a serem seguidas. Em todas as categorias, os alunos que passarem pelo processo seletivo, mas não obtiverem bolsas podem atuar como bolsistas voluntários. Esse vínculo é reconhecido institucionalmente de forma que todos recebem uma declaração de participação na categoria 'bolsista voluntário' ao final de seu percurso.

${ }^{3} \mathrm{AE}$ - Ato Executivo
} 
Para o presente estudo, destaco os objetivos específicos (a), (c) e (e) que foram elementos centrais para a configuração do projeto de ID que apresento exatamente por irem de encontro a duas demandas identificadas nas falas dos alunos que me procuravam para: [1] solicitar ajuda em relação a como planejar aulas e selecionar material para ensinar inglês para crianças da Educação Infantil e do Ensino Fundamental I, uma vez que já estavam atuando nesses níveis de ensino em escolas particulares da região e [2] conversar sobre a ausência desse conteúdo em sua formação acadêmico-profissional, ecoando a voz de pesquisadores e de professores formadores que tratam dessa lacuna, conforme apresentado em seção anterior. Tais questões se fizeram presentes na justificativa dada ao projeto de ID com foco na formação docente e em uma abordagem pedagógica para LIC, conforme pode ser visto abaixo:

\begin{abstract}
A formação de docentes para o ensino de língua inglesa nos cursos de graduação não costuma oferecer disciplinas que contemplem o ensino de língua estrangeiras para crianças [LEC] (ROCHA, 2006; 2007). Possivelmente essa prática seja reflexo das disposições legais contidas na Lei de Diretrizes e Bases da Educação (Lei No 9.394, de 20 de dezembro de 1996) que, no quinto parágrafo do artigo 26, prevê o oferecimento obrigatório de, pelo menos, uma língua estrangeira moderna na parte diversificada do currículo a partir da quinta série. No entanto, o que se percebe, é a existência de cursos de idiomas, de escolas de educação infantil e de ensino fundamental que oferecem aulas de inglês, ministradas, muitas vezes por professores sem formação na área, ou por professores que, embora tenham graduação em Letras (Port./Ing.), não tiveram qualquer contato com propostas metodológicas para o trabalho docente voltado para esses níveis de ensino (MORAES BEZERRA, 2011, p.1).
\end{abstract}

Embora não haja, como mencionado anteriormente, um documento nacional específico que aponte diretrizes para o ensino de LEC na Educação Infantil e no Ensino Fundamental I, os objetivos gerais para a Educação Infantil, expressos em capacidades no RCNEI (BRASIL, 1998b), fundamentam o projeto desse segmento, sendo referência para a proposta de planejamento de aulas, produção de atividades e material. Já os objetivos gerais do Ensino Fundamental I expressos nos PCN-Introdução [1 ${ }^{\mathrm{a}}$ a $4^{\mathrm{a}}$ série] (BRASIL, 1997), em especial os destacados abaixo, servem de base para o trabalho que vimos desenvolvendo com aprendizes em uma escola da rede municipal em São Gonçalo - RJ. 
- compreender a cidadania como participação social e política, assim como exercício de direitos e deveres políticos, civis e sociais, adotando, no dia a dia, atitudes de solidariedade, cooperação e repúdio às injustiças, respeitando o outro e exigindo para si o mesmo respeito;

- posicionar-se de maneira crítica, responsável e construtiva nas diferentes situações sociais, utilizando o diálogo como forma de mediar conflitos e de tomar decisões coletivas;

- conhecer características fundamentais do Brasil nas dimensões sociais, materiais e culturais como meio para construir progressivamente a noção de identidade nacional e pessoal e o sentimento de pertinência ao País;

- conhecer e valorizar a pluralidade do patrimônio sociocultural brasileiro, bem como aspectos socioculturais de outros povos e nações,posicionando-se contra qualquer discriminação baseada em diferenças culturais, de classe social, de crenças, de sexo, de etnia ou outras características individuais e sociais;

- perceber-se integrante, dependente e agente transformador do ambiente, identificando seus elementos e as interações entre eles, contribuindo ativamente para a melhoria do meio ambiente;

- desenvolver o conhecimento ajustado de si mesmo e o sentimento de confiança em suas capacidades afetiva, física, cognitiva, ética, estética, de inter-relação pessoal e de inserção social, para agir com perseverança na busca de conhecimento e no exercício da cidadania;

- conhecer e cuidar do próprio corpo, valorizando e adotando hábitos saudáveis como um dos aspectos básicos da qualidade de vida e agindo com responsabilidade em relação à sua saúde e à saúde coletiva;

- utilizar as diferentes linguagens - verbal, matemática, gráfica, plástica e corporal- como meio para produzir, expressar e comunicar suas ideias, interpretar e usufruir das produções culturais, em contextos públicos e privados, atendendo a diferentes intenções e situações de comunicação. (BRASIL, 1997, p. 69).

O projeto "Ensino de Inglês Para Crianças: Formando Professores Reflexivos" temas linhas mencionadas abaixo enquanto arquitetura teórico-pedagógica-prática para a formação docente e para a abordagem de LIC:

Prática Exploratória - Da proposta do projeto de ID, destaco o trecho abaixo sobre a orientação do processo formativo:

O fio condutor do trabalho docente, em seu viés de ensino-pesquisareflexão, será feito pela Prática Exploratória [...]. A formação docente inicial que se quer coconstruir com os licenciandos com foco no ensino de inglês para crianças articula-se necessariamente a uma perspectiva de reflexão em relação à prática docente. Tal atitude reflexiva não é entendida, no presente projeto, como algo imposto ao professor [...], mas como elemento inerente às competências que o professor de línguas deve desenvolver para se constituir enquanto sujeito do seu fazer e profissional em constante interlocução com seus colegas. Neste viés, é crucial para o licenciando perceber-se como participante de um grupo que, em conjunto, busca entender questões que o 


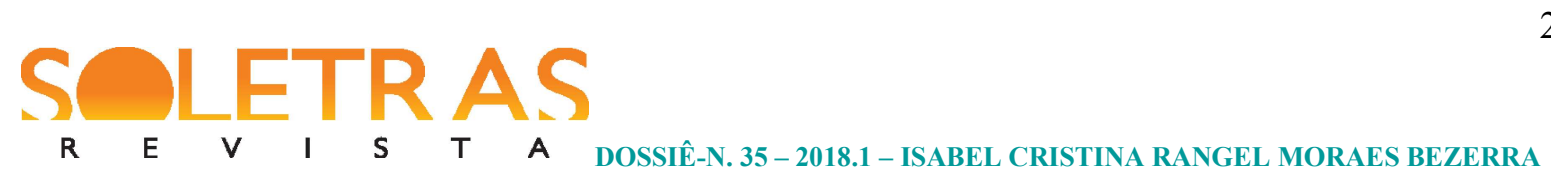

intrigam acerca da vida em sala de aula, sobre o planejar e produzir material para o ensino de língua inglesa para crianças. [...] Dessa forma, a Prática Exploratória, através de seus princípios [...], abre espaço para o questionamento sobre a vida em sala de aula e fora dela ao mesmo tempo em que o ensino de língua inglesa é conduzido, fazendo do processo um lugar de desenvolvimento mútuo de todos os envolvidos, uma vez que a ação para ensinar-aprender-refletir transforma o grupo em uma comunidade de prática reflexiva (MORAES BEZERRA, 2011, p.1).

. Teorização vygotskiana de aprendizagem;

. Natureza sociointeracional da linguagem - No trecho abaixo, retirado do projeto, esse entendimento é explicitado:

Para dar suporte a essa proposta de formação docente, trago o entendimento de que aprender uma língua é aprender uma forma de agir e estar no mundo social [...]. Assim sendo, quando aprendemos uma língua estrangeira, estamos aprendendo a perceber outras visões de mundo, outras formas de movimentação discursiva, outras formas de viver no mundo social. Aprender uma LE, portanto, pode passar a ser uma forma de perceber as diferenças (na etnia; na forma de ser e agir, de alimentar-se, de vestir-se, de morar, etc.) como algo positivo. Ou seja, as diferenças não devem servir para afastar ou ridicularizar, mas devem servir para aproximar e somar [...]. Sendo assim, a formação do professor para ensinar inglês aos aprendizes dos ciclos iniciais do ensino fundamental precisa refletir esses entendimentos e, na prática do planejamento de aulas e atividades, significa oferecer-lhes o contato com a língua inglesa, sem, no entanto, tomar tal língua como uma melhor forma de construção de entendimentos entre interlocutores do que a língua portuguesa, nem entender que seus falantes sejam superiores [...]. Significa, conforme já apontado, sensibilizar os aprendizes para a pluralidade, para as diferenças que nem sempre coexistem sem o embate. Assim, os licenciandos terão a oportunidade de pensar que entendimento de língua trazem para o projeto e em que medida precisam ser revistos ou não para alinharem-se a um entendimento de língua enquanto discurso, enquanto ferramenta de ação social, e que deve fundamentar a proposta de planejamento de um curso para crianças (MORAES BEZERRA, 2011, p.1-2).

. O entendimento que ensinar inglês para crianças e formar professores de LIC são práticas que precisam estar sob constante reflexão e pesquisa. Identifico esse movimento nos objetivos que norteiam o projeto de ID:

Objetivo geral: Propiciar aos licenciandos um espaço formativo para refletir criticamente sobre o ensino de língua inglesa para crianças, envolvendo documentos oficiais que orientam o ensino fundamental (primeiro e segundo ciclos), bem como literatura na área de ensino-aprendizagem de línguas estrangeiras (MORAES BEZERRA, 2011, p. 2).

Objetivos específicos: Iniciar e manter, com os licenciandos, um processo de coconstrução de conhecimentos sobre o ensino de inglês para crianças, 
baseado em leitura e discussão de textos pertinentes, formando uma base teórica interdisciplinar.

Analisar, ao final de cada semestre, os elementos surgidos durante o processo de trabalho com os licenciandos a fim de mapear questões que possam contribuir para o campo epistemológico na área de linguística aplicada em que o presente projeto se insere e no qual poderão ser produzidas teorizações sobre, por exemplo, formação docente inicial, construção de identidade profissional, ensino de inglês para crianças, dentre outras (MORAES BEZERRA, 2011, p.3-4).

É a partir desse cenário que trago um pouco do que foi produzido pelas bolsistas sob minha orientação. Quero registrar o agradecimento a Thaís, primeira bolsista do projeto, que foi e é muito importante para o que se fez e faz atualmente. Ela ajudou a construir o planejamento inicial, o material de ensino, envolver outras colegas a participarem como bolsistas voluntárias. Interessada, responsável e pró ativa, ajudou na construção de laços com a primeira escola parceira do projeto, inclusive ministrando as primeiras aulas de inglês produzidas.

\section{Reflexão sobre LIC e experiência docente - a vez da prática}

Abaixo estão os temas que selecionamos inicialmente para gerarem as aulas. Eles foram uma versão criada a partir de outro projeto de LIC desenvolvido no Instituto de Educação Carlos Pasquale, localizado no município de Nilópolis-RJ, onde atuei como professora de inglês para o Curso Normal ${ }^{4}$. Nesse projeto, além de mim, atuaram uma licencianda de uma universidade particular que desenvolvia suas atividades de estágio no referido instituto e dois alunos do curso Normal. Na releitura dos temas do projeto original, as bolsistas e eu construímos a proposta temática abaixo [Proposta 1] que seria desdobrada de diferentes formas nas séries em que atuássemos no ensino fundamental. Digo isso porque, naquele momento, não havíamos ainda estabelecido uma parceria com uma escola da região. Dessa forma, planejamentos e atividades sofreram modificações e ajustes a partir do contato com os aprendizes em situação real de ensino [Proposta 2].

Proposta 1

\begin{tabular}{|c|c|c|}
\hline \multicolumn{2}{|c|}{ Tema } & Foco \\
\hline $\mathbf{1}$ & My Family and I & $\begin{array}{c}\text { Família, relações de parentesco, diferentes formações familiares, o } \\
\text { respeito e a cooperação em família. }\end{array}$ \\
\hline $\mathbf{2}$ & My body & Partes do corpo, cuidados e saúde. \\
\hline
\end{tabular}

\footnotetext{
${ }^{4}$ Curso de formação de professores oferecido em institutos de educação, no nível de ensino médio, e que prepara as alunas e os alunos para atuarem em turmas do primeiro ao quinto ano do Ensino Fundamental I. 


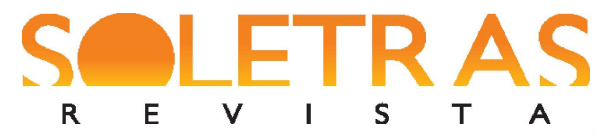

DOSSIÊ-N. 35 - 2018.1 - ISABEL CRISTINA RANGEL MORAES BEZERRA

\begin{tabular}{|c|c|c|}
\hline $\mathbf{3}$ & Sports & $\begin{array}{c}\text { Tipos diferentes de esportes, respeito aos oponentes, obediência a regras, } \\
\text { espírito de competição. }\end{array}$ \\
\hline $\mathbf{4}$ & $\begin{array}{c}\text { My pets and castoff } \\
\text { animals }\end{array}$ & Animais de estimação e animais abandonados, cuidados, respeito. \\
\hline $\mathbf{5}$ & The zoo & O zoológico e seus bichinhos, cores, atitude em lugares públicos. \\
\hline $\mathbf{6}$ & The planet & O lugar onde moramos, lixo, meio ambiente. \\
\hline $\mathbf{7}$ & $\begin{array}{c}\text { Different kinds } \\
\text { of fruit }\end{array}$ & Tipos de frutas, cores, sabores, tamanho. \\
\hline $\mathbf{8}$ & Vegetables & $\begin{array}{c}\text { Tipos de legumes e hortaliças, Alimentação e saúde, dieta balanceada x } \\
\text { alimentação com muitos produtos industrializados. }\end{array}$ \\
\hline
\end{tabular}

Proposta 2

\begin{tabular}{|c|c|c|}
\hline \multicolumn{2}{|r|}{ Tema } & Foco \\
\hline 1 & My Family and I & $\begin{array}{l}\text { Família, relações de parentesco, diferentes formações familiares, o respeito e a } \\
\text { cooperação em família. }\end{array}$ \\
\hline 2 & My body & Partes do corpo, cuidados e saúde. \\
\hline 3 & Sports & $\begin{array}{l}\text { Tipos diferentes de esportes, respeito aos oponentes, obediência a regras, espírito } \\
\text { de competição. }\end{array}$ \\
\hline 4 & $\begin{array}{l}\text { A birthday } \\
\text { party }\end{array}$ & $\begin{array}{l}\text { O que pode haver em uma festa de aniversário infantil; quem são os convidados; } \\
\text { numerais de } 1 \text { a 10; idade; a criança, o jovem e o idoso. }\end{array}$ \\
\hline 5 & $\begin{array}{l}\text { My school and } \\
\text { my friends }\end{array}$ & $\begin{array}{l}\text { Localização da escola, os colegas, respeito às pessoas que trabalham ou estudam } \\
\text { na escola, material escolar, contraste com outras escolas. }\end{array}$ \\
\hline 6 & $\begin{array}{l}\text { My pets and castoff } \\
\text { animals }\end{array}$ & Animais de estimação e animais abandonados, cuidados, respeito. \\
\hline 7 & The zoo & O zoológico e seus bichinhos, cores, atitude em lugares públicos. \\
\hline 8 & The planet & O lugar onde moramos, lixo, meio ambiente. \\
\hline 9 & $\begin{array}{l}\text { Different kinds } \\
\text { of fruit }\end{array}$ & Tipos de frutas, cores, sabores, tamanho. \\
\hline 10 & Vegetables & $\begin{array}{l}\text { Tipos de legumes e hortaliças, Alimentação e saúde, dieta balanceada x } \\
\text { alimentação com muitos produtos industrializados. }\end{array}$ \\
\hline
\end{tabular}

Abaixo segue um fragmento do planejamento com cronograma e objetivo para a primeira unidade. A partir dela, as bolsistas propuseram um planejamento de aula que foi discutido na reunião de orientação antes de ser levado à escola. Após o início do segundo semestre de 2014, apenas Thais atuou em uma escola em São Gonçalo distante do campus de nossa universidade e o fragmento abaixo se refere à sua atuação naquele contexto. Foi chamado de oficina, porque, inicialmente, ela deveria ministrar aulas de português por um projeto de aceleração da aprendizagem para alunos de diferentes séries do Ensino Fundamental I. Pedimos permissão à diretora para que Thais pudesse lecionar a língua inglesa uma vez por semana. O projeto foi encaminhado para a direção e a orientação pedagógica que deram a permissão necessária. 


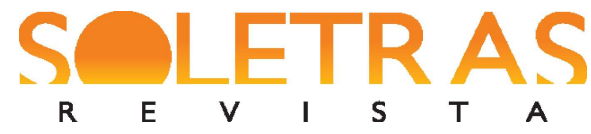

DOSSIÊ-N. 35 - 2018.1 - ISABEL CRISTINA RANGEL MORAES BEZERRA

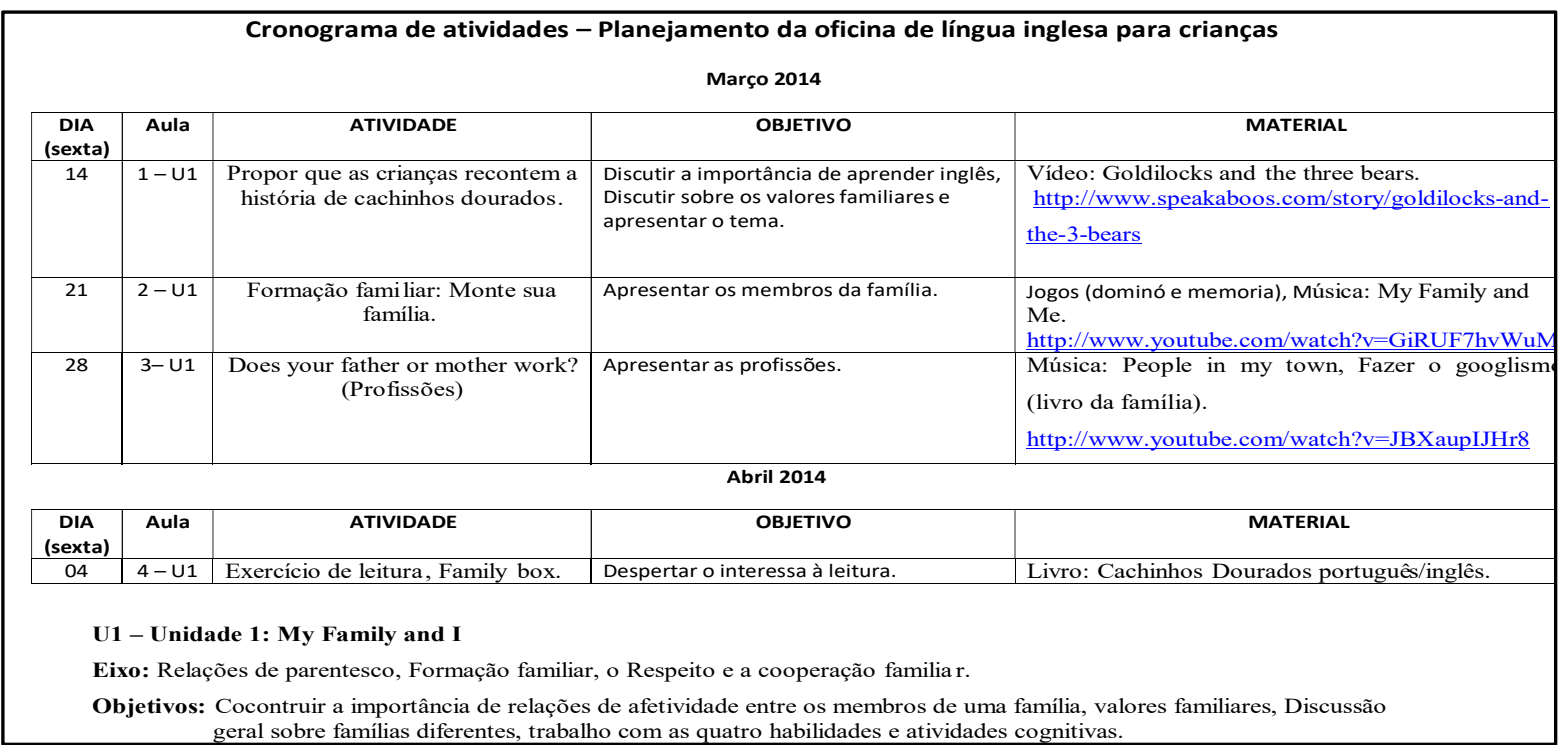

Desse planejamento, ressalto o uso de gêneros próprios para crianças: jogos, música e a história Cachinhos Dourados (Goldilocks and the three bears) em português que foi adaptada ao tema e contada para os alunos, tendo algumas palavras chave do tema e da história traduzidas para inglês (mother, father, girl, bear, house, bed, por exemplo). Buscamos fazer com que as palavras aparecessem em um contexto de uso, partindo do conhecido, ou dos esquemas de conhecimento (ONRUBIA, 1999) dos alunos, para, através de 'ajudas ajustadas', iniciarem a construção de conhecimento em língua inglesa. Ressalto ainda, o alinhamento ao RCNEI (BRASIL, 1998b) e aos temas transversais ao focalizara 'importância das relações de afetividade' entre familiares e 'discussão geral sobre famílias diferentes', contemplando a reflexão conjunta sobre relação com o outro em um mundo plural, multicultural, buscando construir atitudes positivas da criança em relação às diferenças refletindo, igualmente, sobre a qualidade de vida (GIEVE; MILLER, 2006) na família. Posteriormente, em 2015, conseguimos permissão para atuar em outra escola mais próxima do campus, no mesmo município. Assim, outras alunas puderam implementar o projeto nesse novo contexto. Os planejamentos já feitos serviram de base inicial para a atuação, mas eram sempre revistos e atualizados de acordo com as demandas e necessidades dos aprendizes. Nessa escola, as bolsistas atuavam em duplas ou trios, em aulas de cinquenta minutos e que aconteciam uma vez por semana. A professora regente da turma sempre estava presente.

Ao trabalharem com o tema da família, envolvendo os pequenos aprendizes de uma turma para produzirem uma arvore genealógica que pudesse representar suas famílias, as 


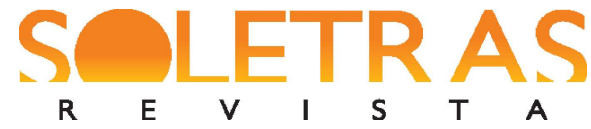

DOSSIÊ-N. 35 - 2018.1 - ISABEL CRISTINA RANGEL MORAES BEZERRA

bolsistas fizeram uma observação que foi discutida na reunião de orientação. Isso foi registrado por Rodrigues (2018, p. 22) em sua monografia:

Logo no início da atividade os alunos perceberam que seria uma tarefa difícil montar a árvore genealógica deles porque a maioria das fotos das revistas era composta por pessoas brancas, bonitas, felizes e as paisagens eram sempre lindas. A escola em que o projeto foi aplicado é uma escola de periferia e a maioria dos alunos é negra. Logo após a finalização da atividade, nós perguntamos: o que vocês acharam da atividade? Essas figuras realmente representam a família de vocês? A partir das respostas deles nós identificamos que essa atividade poderia servir para trazer questões sérias do cotidiano daqueles alunos como, por exemplo: exclusão social, racismo, o modelo de família patriarcal, entre outros. [...] Eles disseram que não, pois a grande maioria das pessoas da revista eram brancas, ricas e bonitas e que geralmente era uma família tradicional com esposo, esposa e dois filhos, praticamente não havia espaço para as diferenças e nem para pessoas idosas e deficientes.

Esse primeiro excerto registra um movimento de olhar e ouvir com mais cuidado que Rodrigues e suas colegas lançaram ao desenvolvimento da atividade, notando a dificuldade dos alunos em desenvolverem a tarefa não por dificuldade cognitiva, mas por ausência de elementos no material impresso que pudessem utilizar. A atividade embora não tenha sido pensada para ser uma APPE, já estava mobilizando o grupo de bolsistas e crianças para 'estranharem' a representação de pessoas em revistas. As bolsistas começaram a propor perguntas aos alunos iniciando o processo de envolvimento reflexivo coletivo e colaborativo. Rodrigues (2018, p.23) segue seu relato:

Nós resolvemos na aula seguinte levar cartazes para a classe, os separamos em cinco grupos, levamos novamente as revistas e pedimos para que eles utilizassem novamente as imagens da revista para responder a seguinte puzzle no cartaz: "Por que Minha Family não está representada nas revistas? "A partir dessa atividade, foi possível observar que apesar da pouca idade de alguns alunos da turma, eles eram capazes de refletir sobre questões importantes e delicadas como: a exclusão social das pessoas que são menos favorecidas economicamente, das diferentes constituições de famílias, dos idosos e deficientes, entre outros.Após essa atividade junto à experiência vivenciada no projeto, eu constatei que através de materiais empíricos e não somente conhecimentos teóricos a importância da escola fornecer um ensino de qualidade e integral visando a formação cidadã do aluno, deixar de fora da sala de aula questões como as que foram levantadas pela atividade descrita acima, é prejudicial aos alunos, nós devemos sempre instigá-los a ter o pensamento crítico e não aceitar tudo o que lhes é imposto, é preciso ter 


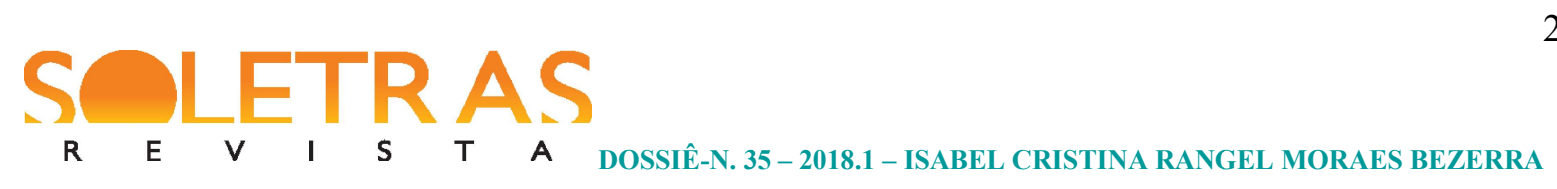

opinião sobre as questões sociais que fazem parte de cotidiano em que eles estão inseridos.

No segundo fragmento, Rodrigues registra a sequência do processo de refletir, quando envolvem os pequenos aprendizes para fazerem uma leitura crítica das representações da revista, o que considero um evento de letramento crítico. Dessa vez era uma APPE planejada e havia um puzzle explícito a guiar o duplo movimento de ensinar-aprender e refletir: 'Por que Minha Family não está representada nas revistas?' Ressalto o trecho em que Rodrigues aponta como a pouca idade não foi impedimento para que as crianças refletissem e discutissem sobre questões delicadas que faziam parte de suas vidas. As licenciandas e as crianças vivenciavam, na prática, o letramento crítico ao tratarem a língua e as representações semióticas em sua perspectiva sociointeracional e ideológica no sentido bakhtiniano. As licenciandas, através de sua ação pedagógica, mediada pela linguagem, construíram ZDPs que propiciaram aos alunos o aprendizado sobre a língua e a reflexão exploratória sobre a vida em seu contínuo dentro e fora de sala de aula. Os grupos produziram pôsteres registrando seus entendimentos e os apresentaram à turma. A imagem abaixo exemplifica uma dessas produções.

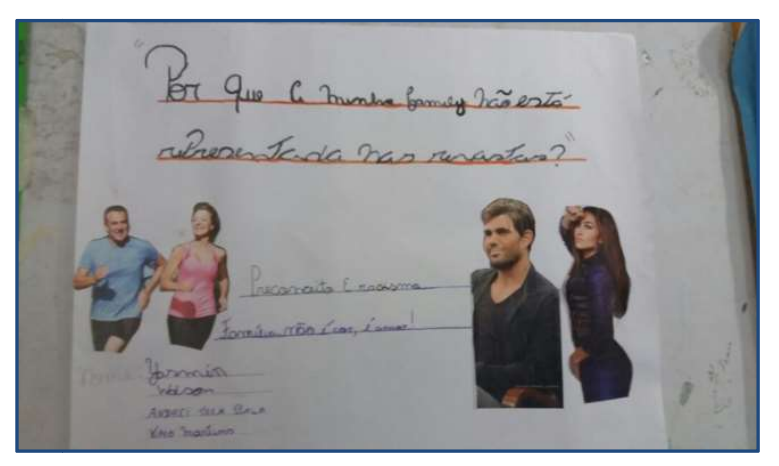

\section{Entendimentos locais partilhados}

Ao longo de minha experiência docente, percebo o quanto meus alunos e, no caso do projeto de ID, as bolsistas se desenvolvem como aprendizes que levam seu aprendizado a sério e fazem isso melhor em um ambiente de suporte mútuo, conforme Allwright e Hanks (2009). Esse processo de aprendizagem no projeto é via de mão dupla para as bolsistas e para mim, assim como para elas e para os pequenos aprendizes que lhes têm ajudado a entender o significado da docência ética, engajada e envolvida, de certa forma, com a justiça social. Por 


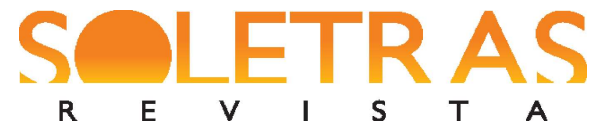

DOSSIÊ-N. 35 - 2018.1 - ISABEL CRISTINA RANGEL MORAES BEZERRA

isso, para terminar esse artigo, valho-me de alguns fragmentos do relatório de bolsista escrito por Rodrigues, em 2015.

A primeira coisa que eu aprendi foi que o projeto não me daria uma "fórmula" pronta para ensinar inglês para crianças, que a PE não era um simples "método" de ensino que tornaria mais fácil o ensino infantil, que essa teoria não seria a "solução" dos meus problemas em sala de aula. O que eu aprendi, ou melhor, ainda estou aprendendo é que a PE nos ajuda a ter uma qualidade de vida em sala de aula, nos ajuda a olhar o aluno não apenas como um número de uma chamada, mas sim como um ser humano que tem suas questões e sentimentos e que eles trazem sua bagagem cultural, social e emocional para a sala de aula [...]

Saber a opinião dos alunos sobre o que está sendo ensinado e sobre as atividades desenvolvidas, diminui o risco da frustração do aluno ter a sensação de ser obrigado a fazer algo que ele não queira e também diminui o desinteresse na matéria, pois ele sabe que ele tem voz e que caso ele sugira algo as professoras, nós levaremos em conta e tentaremos fazer alguma atividade com o que eles sugeriram. Dessa forma o ensino deixa de ser algo autoritário e passa a ser mais cooperativo [...] Para concluir acredito que eu ainda tenho uma longa caminhada pela frente nos estudos de PE, ainda há muito que aprender e refletir sobre a minha prática de ensino, mas o que eu já tenho certeza é que a minha postura como professora já mudou.

Esses trechos trazem entendimentos construídos na vivência com todos no projeto e na escola em que o projeto vem sendo implementado: instala-se a 'ação para entender e não para controlar'. Na verdade, contribuem para que eu perceba, pelo olhar dessa bolsista, que a proposta de 'não agir para mudar da $\mathrm{PE}$ ' vem provocando transformações profundas e sustentáveis.

\section{Referências bibliográficas}

ALLWRIGHT, D. Prioritizing the human quality of life in the language classroom: is it asking too much of beginning teachers? In GIL, G.; VIEIRA-ABRAHÃO, M.H. (orgs.) Educação de Professores de Línguas - os desafios do formador. Campinas: Pontes Editores, 2008 .

.From teaching points to learning opportunities and beyond. TESOL Quarterly, v.39, p. 9-31, 2005.

.Three major processes of teacher development and the appropriate design criteria for developing and using them. In: JOHNSTON, B.; IRUJO, S. (eds.) Research and practice in language teaching education - Voices from the field. Center for Advanced Research on Language Acquisition. Minneapolis, 1999, p. 101-118. Disponível em: http://carla.umn.edu 


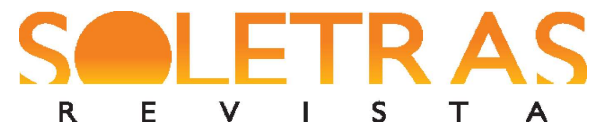

DOSSIÊ-N. 35 - 2018.1 - ISABEL CRISTINA RANGEL MORAES BEZERRA

/resources/working-papers/documents/ResearchPracticeLanguageTeacherEducation.pdf Acesso: 12 ago. 2013. (mimeo).

Integrating training and development: the role of research. Lancaster, 1996

ARAOS, M. Examining Challenges and Complexities in the Chilean Young Learners Classroom: A Case of Teaching English as a Foreign Language. PhD.The University of Sheffield, 2015.

BAKHTIN, M. Marxismo e filosofia da linguagem. São Paulo: Hucitec, 1981.

BANFI, C. English Language Teaching Expansion in South America: Challenges and Opportunities. In KAMHI-STEIN, L.D.; DIAZ MAGGIOLI; OLIVEIRA, L.C. (eds.) English Language Teaching in South America: Policy, Preparation and Practices. Clevedon: Multilingual Matters, 2015.

BAZERMAN, C. Gêneros Textuais, Tipificação e Interação. DIONÍSIO, A. P.; HOFFNAGEL, J. C. (org.). São Paulo: Cortez, 2005.

BERNACHI, L. F. Um convite à aprendizagem exploratória e colaborativa: uma [re]vista para a família. Monografia (Graduação Letras - Port./Ing.). São Gonçalo: Dep. de Letras, FFP-UERJ, 2016.

BRASIL. Parâmetros Curriculares Nacionais: Terceiro e Quarto Ciclos do Ensino Fundamental:Língua Estrangeira. Brasília: MEC/SEF, 1998a.

$1998 b$.

Referencial curricular nacional para a educação infantil. Brasília: MEC/SEF,

Parâmetros curriculares nacionais: introdução aos parâmetros curriculares nacionais. Secretaria de Educação Fundamental. Brasília: MEC/SEF, 1997.

.Conhecimentos de Línguas Estrangeiras. In: Orientações Curriculares para o Ensino Médio. Linguagens, Códigos e suas Tecnologias. Brasília: Ministério da Educação, Secretaria de Educação Básica, 2006.

CAMERON, L. Challenges for ELT from the expansion in teaching children. ELT Journal, v. 57/2, p. 105-112, 2003.

2001.

. Teaching Languages to Young Learners. Cambridge: Cambridge University Press,

CRISTÓVÃO, V.L.L.; GAMERO, R. Brincar aprendendo ou aprender brincando? O inglês na infância. Trabalhos em Linguística Aplicada. Campinas, 48(2), jul./dez., 2009. Disponível em: $<$ http://www.scielo.br/scielo.php?pid=S0103-8132009000200005\&script $=$ sci_abstract\& tlng $=\mathrm{pt}>$ 


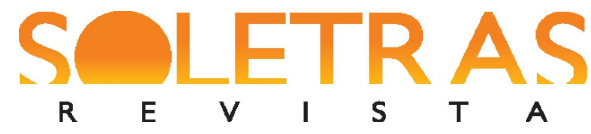

DOSSIÊ-N. 35 - 2018.1 - ISABEL CRISTINA RANGEL MORAES BEZERRA

FAIRCLOUGH, N. Critical discourse analysis. Londres: Longman, 1995.

. Discourse and social change. Cambridge: Polity Press, 1992.

.Language and power. Londres: Longman, 1989.

FERREIRA, A. J. Refletindo sobre a interação no processo de aprendizagem: construindo entendimentos para a qualidade de vida em sala de aula de LIC.Monografia (Graduação Letras - Port./Ing.). São Gonçalo: Dep. de Letras, FFP-UERJ, (em andamento).

FREIRE, P. FAUNDEZ, A. Por uma pedagogia da pergunta. Rio de Janeiro: Paz e Terra, 2011.

GIEVE, S.; MILLER, I.K. (Eds.). Understanding the Language Classroom. Basingstoke: Palgrave Macmillan, 2006.

JANKS, H. Panorama sobre letramento crítico. In: JESUS, D. M.; CARBONIERI, D. (org.) Práticas de Multiletramento e Letramento Crítico: outros sentidos para a sala de aula de linguas. Campinas: Pontes Editores, 2016, p. 21-39.

LIMA, A. P.; MARGONARI, D. M. A prática de ensino e a formação de professores de inglês. In ROCHA, C.H., TONELLI, J. R.A.; SILVA, K.A. (orgs.) Campinas: Pontes, 2010.

LONDRINA. Guia Curricular para a Língua Inglesa - Educação Infantil e Ensino Fundamental. 2013. Acesso: junho/2015. Disponível em: http://www.uel.br/eventos/epic/ pages/arquivos/Guia\%20Curricular\%20versao\%20final.pdf

MITCHELL, R.; MYLES, F. Second Language Learning Theories. London: Arnold, 2002.

MILLER, I. K. Formação de professores de línguas: da eficiência à reflexão crítica e ética. In: MOITA LOPES, L. P. Linguística Aplicada na Modernidade Recente. São Paulo: Parábola, 2013, p. 99-121.

- 'Puzzle-driven' language teacher development: the contribution of Exploratory Practice. In YOSHIDA, T. et al. (Eds.) Researching Language Teaching and Learning - An Integration of Practice and Theory. Oxford: Peter Lang, 2009.

- Construindo parcerias universidade-escola: caminhos éticos e questões críticoreflexivas. In: GIMENEZ, T.; MONTEIRO, M.C. de G. (Orgs.) Formação de Professores de Línguas na América Latina e Transformação Social. Campinas: Pontes Editores, 2010, p. 109-129.

; MORAES BEZERRA. I. C. R. Professor: um profissional em construção permanente. Revista Pesquisa em Discurso Pedagógico. Departamento de Letras, PUC- Rio, v.2, 2007, p. 1-9. Disponível em: <https://www.maxwell.vrac.pucrio.br/10957/10957.PDFXXvmi> 


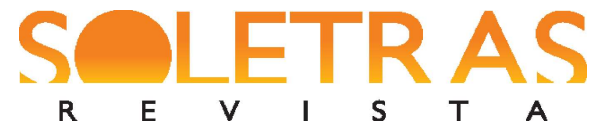

DOSSIÊ-N. 35 - 2018.1 - ISABEL CRISTINA RANGEL MORAES BEZERRA

.; CUNHA, M. I. de A.; MORAES BEZERRA. I. C. R.; NÓBREGA, A. N.; EWALD, C. X.; BRAGA, W.G.Teaching English to Young Learners: Some Reflective Voices from Latin America. In: GARTON, S.; COPLAND, F. (eds.) The Routledge Handbook of Teaching English to Young Learners, Routledge, no prelo.

MOITA LOPES, L. P. Oficina de Linguística Aplicada. Campinas: Mercado de Letras, 1996.

Socioconstrucionismo: Discurso e Identidades Sociais. In MOITA LOPES, L.P. (org.) Discursos de identidades: discurso como espaço de construção de gênero, sexualidade, raça, idade e profissão na escola e na família. Campinas: Mercado de Letras, 2003, p. 13-38.

MORAES BEZERRA, I. C. R. Formação de Professores de Inglês: embate e caminhos na construção do conhecimento e da identidade profissional. Dissertação de Mestrado no Programa Interdisciplinar de Linguística Aplicada. Rio de Janeiro: Faculdade de Letras, UFRJ, 2000.

Prática Exploratória: um caminho para o entendimento. Revista Pesquisa em Discurso Pedagógico, Rio de Janeiro, V. 2, n.2, 2003. p. 58-72. Disponível em:

$<$ http://www.letras.pucrio.br/unidades\&nucleos/epcentre/eprecent/Webgrupo_WebIPELIsabe 1.htm>

; SANTOS, M. R. Língua inglesa para crianças e um projeto de iniciação à docência: formação inicial exploratória. Mimeo.

OLIVEIRA, M. K. O problema da afetividade em Vygotsky. In: LA TAILLE, Y. Piaget, Vygotsky, Wallon: teorias psicogenéticas em discussão. Summus Editorial, 1992, p. 75-84.

ONRUBIA, J. Ensinar: criar zonas de desenvolvimento proximal e nelas intervir. In: $O$ Construtivismo na Sala de Aula. São Paulo: Editora Ática, 1999, p. 123-151.

PINTER, A. Teaching young language learners. Oxford: Oxford University Press, [2006]2015.

PONTECORVO, C. A contribuição da perspectiva vygotskiana à psicologia da educação. In: ; AJELLO, A.M.; ZUCCHERMAGLIO, C. Discutindo se Aprende: interação social, conhecimento e escola. Porto Alegre: Artmed, 2005, p. 15-30.

PORTO, M. English Language Education in Primary Schooling in Argentina. Education Policy Analysis Archives, 24(80), 2016, p. 1-25. Disponível em: <http://dx.doi.org/10.14507 /epaa.24.2450> Acesso: 10 out. 2016.

RAJAGOPALAN, K. Entrevista concedida à Revista de Letras Norteamentos. Estudos Linguísticos, Sinop, v. 4, n.8, ju./dez., 2011. Acesso: outubro, 2016. Entrevistadores: Kleber A. da Silva, Leandra I. Seganfredo Santos, Olandina D. Justina. Disponível: http://sinop. unemat. br/ projetos/revista/index.php/norteamentos/article/ viewFile/ 812/566

REITORIA - UERJ. Ato Executivo-027, 1999. Disponível:<http://www.fssestagio. uerj.br/legislacao/ato02799.pdf > Acesso: dezembro 2010. 


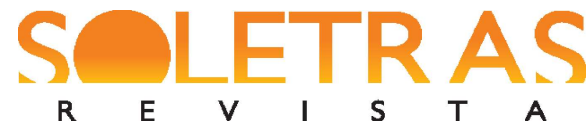

DOSSIÊ-N. 35 - 2018.1 - ISABEL CRISTINA RANGEL MORAES BEZERRA

RODRIGUES, H. M. da. Ensino de Inglês para Crianças: reflexão sobre a Prática Exploratória no processo de formação integral do aluno. Monografia (Graduação Letras Port./Ing.). São Gonçalo: Dep. de Letras, FFP-UERJ, em andamento.

ROCHA, C. H. Provisões para ensinar LE no ensino fundamental de $1^{a}$ a $4^{a}$ séries: dos parâmetros oficiais e objetivos dos agentes. Dissertação de Mestrado. Campinas: IEL/UNICAMP, 2006.

O Ensino de Línguas para Crianças no Contexto Educacional Brasileiro: Breves Reflexões e Possíveis Provisões. D.E.L.T.A., Vol. 23(2), 2007. p. 273-319. Disponível em: $<$ http://dx.doi.org/10.1590/S0102-44502007000200005> Acesso: junho/2010.

A língua inglesa no Ensino Fundamental I público: diálogos com Bakhtin por uma formação plurilíngue. Trabalhos em Linguística Aplicada. Campinas, 48(2), jul./dez., 2009 , p. 247-274. Disponível em: <http://www.scielo.br/scielo.php?pid=S0103-8132009000200006 $\&$ script $=$ sci_abstract\&tlng $=$ pt $>$ Acesso em 08 jun. 2010.

SANTOS, L. I. S. Crenças acerca da inclusão de língua inglesa nas séries iniciais. Contexturas, n. 10, 2006.

.; BENEDETTI, A. M. Professor de Língua Estrangeira para Crianças: Conhecimentos Teórico Metodológicos Desejados. Trabalhos em Linguística Aplicada, vol. 48(2), 2009, p. 333-351. Disponível em: <https://periodicos.sbu.unicamp.br/ojs/index.php/tla/article/view/ 8645229> Acesso em: 02 jul. 2010.

SANTOS, M. R. O afeto no processo de ensino-aprendizado de língua inglesa para crianças. Monografia (Graduação Letras - Port./Ing.). São Gonçalo: Dep. de Letras, FFP-UERJ, em andamento.

SILVA, T. P. Coconstruindo o ensino de inglês para crianças: elaboração de material didático e formação integral. Monografia (Graduação Letras - Port./Ing.). São Gonçalo: Dep. de Letras, FFP-UERJ, 2015.

TONELli, J. R.A; CRISTOVÃO, V. O Papel dos Cursos de Letras na Formação de Professores de Inglês para Crianças. Calidoscópio, 8(1), 2010, p. 65-76. Disponível: $<$ http://revistas.unisinos.br/index.php/calidoscopio/article/view/159 > Acesso em: 15 Abr. 2012.

VYGOTSKY, L.S. Pensamento e Linguagem. São Paulo: Martins Fontes, [1987] 2008. . A formação Social da Mente. São Paulo: Martins Fontes, [1987] 2008.

UERJ-REITORIA. Ato Executivo-027, 1999. Disponível: $<$ http://www.fssestagio.uerj.br/ legislacao/ato02799.pdf > Acesso: março/2009. 


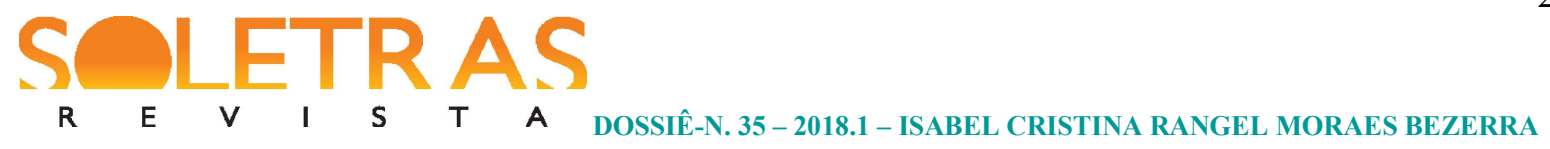

\title{
"They were able to reflect upon important and delicate issues": building knowledge through a TEYL teacher development project
}

\begin{abstract}
In Brazilian universities, undergraduate courses of Letters and Arts do not offer subjects on the teaching of foreign languages to young learners [TFLYL] in initial teacher education programs, nor on the teaching of English to young language learners [TEYL], more specifically, despite the need for such professionals in schools of the private and public sectors. In this scenario, there is room for the initial education project I supervise and that aims at offering a discursive place for the construction of knowledge as well as for generating some critical thinking about teaching and learning. Thus, based on previous research in the area (PINTER, [2006]2015; SEGANFREDO; BENEDETTI, 2009; CRISTÓVÃO; GAMERO, 2009), I present the theoretical framework that founds an approach to TEYL as well as to teacher education. Backed by Exploratory Practice and its principles (ALLWRIGHT, 1996; MILLER, 2013), which form a hybrid approach to teaching-learning, teacher education and reflexive practice, instead of results I bring some understandings on initial teacher development generated from the teacher development project presented in this article. These local understandings can, in turn, contribute to deepen the discussions on TEYL and on initial teacher education for such public.
\end{abstract}

Keywords: Pre-service teacher education. Exploratory Practice.Teaching English to young language learners. Critical literacy.

Recebido em 05 de fevereiro de 2018.

Aprovado em 03 de abril de 2018. 